\title{
The Teacher as One of the Factors Influencing Students' Perception of Biology as a School Subject
}

Milan Kubiatko ${ }^{\star 1}$, Gregor TorkaR ${ }^{2}$ ANd Lenka Rovnanova ${ }^{3}$

$\approx$ The main aim of our research was to determine whether the teacher is one of the factors influencing students' perception of biology as a school subject. The study also aimed to identify the influence of certain other factors in this regard, specifically: students' gender and place of residence, the number of biology teachers who have taught the students, and the teachers' gender. The sample consisted of 261 lower secondary school students (ISCED 2) in Slovakia, aged 14 and 15 years. A questionnaire with Likert-type items was used as a research instrument. The findings confirm the impact of the biology teacher on students' perception of the subject. After removing the influence of the teacher, the students' gender and place of residence did not have any significant influence on their perception of the subject. Two additional significant variables were the number of biology teachers who had taught the students and the teachers' gender. The research confirmed that the teacher's personality is one of the significant factors that can influence students' perception of school subjects.

Keywords: biology, perception, school subject, teacher, lower secondary school students

1 * Corresponding Author. University of Zilina, Faculty of Humanities, Department of Pedagogical Studies, Slovakia; mkubiatko@gmail.com.

2 University of Ljubljana, Faculty of Education, Slovenia.

3 Matej Bel University, Faculty of Education, Department of Pedagogy, Slovakia. 


\section{Učitelji_ce kot en od vplivnih dejavnikov učenčeve_kine percepcije predmeta biologija}

Milan Kubiatko, Gregor Torkar in Lenka Rovnanova

$\propto$ Glavni namen naše raziskave je bil ugotoviti ali je učitelj_ica en od dejavnikov, ki vpliva na percepcijo biologije kot šolskega predmeta. Namen raziskave je identificirati tudi nekatere druge vplivne dejavnike, kot so: spol učenk_cev, kraj bivanja, število učiteljic_jev biologije, ki so poučevale_i učenko_ca, ter spol učitelja_ice. Vzorec sestavlja 261 slovaških učenk_cev (dijakinj_ov nižje srednje šole) (ISCED 2), starih med 14 in 15 let. Uporabljen je bil vprašalnik s trditvami Likertovega tipa. Rezultati raziskave potrjujejo vpliv učitelja_ice biologije na učenčevo_ kino percepcijo predmeta biologija. Po izločitvi vpliva učitelja_ice, spol učenk_cev in kraj bivanja nista imela signifikantnega vpliva na njihovo percepcijo predmeta. Za signifikantna vpliva pa sta se izkazala število učiteljic_ev biologije, ki so poučevale_i učenko_ca, ter spol učitelja_ice. Raziskava torej potrjuje, da je učiteljičina_eva osebnost pomemben dejavnik, ki vpliva na učenčevo_kino percepcijo šolskih predmetov.

Ključne besede: biologija, percepcija, šolski predmet, učitelj, učenci 


\section{Introduction}

Science subjects are not considered to be among the favourite subjects of lower secondary school students. Francis et al. (2003), for example, reported that 14-year-old students had negative attitudes to science subjects and positive attitudes to their native language. Colley and Comber (2003) found that age and gender had no significant influence on students' attitudes to science subjects. Many studies have shown that teachers have a substantial effect on how students learn. Luyten and Snijders (1996) reported some positive long-term effects of teachers' teaching efficiency, their knowledge of students' needs and their motivation on students' perception of a school subject. In addition, the length of teaching by the same teacher proved to be relevant factor. Godhaber and Brewer $(1997,2000)$ and Wayne and Young (2003) found that students had a more positive perception of mathematics if their teachers had a higher qualification. Two other factors influencing students' perception of school subjects and their academic achievement are teachers' pedagogical mastery and effective use of teaching methods. These two factors have a greater impact on students' attitudes than pedagogical content knowledge (Darlin-Hammond, 1999). Feng and Ha (2016) investigated the impact of teachers' information literacy on lifelong learning and school effectiveness, finding that it can improve students' perception of teaching and teachers. Similarly, Byrne (1983) found that, in addition to good content knowledge, the way of presenting content to students is an important predictor of good teaching. The use of appropriate analogies, illustrations, practical examples, explanations and demonstrative examples are important for the perception of school subjects. Juttner et al. (2013) claimed that a good and effective teacher possesses a mix of good content knowledge, knowledge of students' prior content knowledge, and a mastery of different teaching strategies and methods. As Schreerens (2007, 2008) indicated, the teaching process is influenced by six factors: the school curriculum, team-work of the class and the teacher, a traditional teaching strategy, a constructivist teaching strategy, the school climate and evaluation. An effective teaching process can lead to a positive perception of a subject among students.

The teaching process in biology can vary greatly in terms of teaching approaches and strategies. It can take place in the classroom, in a natural environment, in the laboratory, in a museum, etc. George and Kaplan (1998) found that non-formal learning situations (i.e., museums, libraries, zoos, etc.) positively influence students' attitudes towards science subjects. Similar findings were reported by Haladyna, Olsen and Shaughnessy (1983) and Myers and Fouts (1992). A biology teacher has many opportunities to make the subject more interesting for students, thus contributing to the formation of students' positive attitudes 
towards biology. Singh, Granville and Dika (2002) studied different factors influencing students' perception of mathematics and biology. They found that when a teacher presented subject content during school lessons in an understandable and meaningful form and tried to apply the content to real-life situations, he or she encouraged more positive student attitudes towards biology and mathematics. If the students were convinced about the benefits of the subject for their future career, they had positive attitudes towards the subject. The authors also found a significant positive relationship between students' attitudes towards the subject and their academic achievement. Teppo and Rannikmäe (2003) found that students' interest in a school subject was improved if the teacher was able to present the curriculum in a way that was interesting to them, if they regarded the information presented as useful, and if they were able to identify a connection with real life. The authors also compared the results by gender. They found that female students preferred teachers who presented information about the human body and human health, whereas male students preferred teachers who were interested in the curriculum focused on inanimate objects.

Cohen (2005) reported a positive relationship between the teacher's personality and the preferences for elective school subjects among students. The majority of students chose the subject according to the teacher.

Trumper (2006) analysed changes in the science subject curriculum in Israel. Among other factors, the author mentioned the influence of the teacher on attitudes towards the subject. Zeidan (2010) analysed students' attitudes toward biology according to the social and political context in which the teaching process was realised. Female students perceived biology in a more positive way than male students. The author explained that this could partly be a result of the positive relationship of female students with the teacher. In Palestine, men are typically more focused on political questions, while women are more focused on education.

The number of studies focusing on the influence of the teacher on the perception of biology or other school subjects is relatively low. The main aim of the present research was to determine whether the teacher is one of the influential factors that shapes lower secondary school students' perception of biology as a school subject (ISCED 2) in Slovakia. The study also aimed to identify the influence of certain other factors in this regard, specifically: students' gender and place of residence, the number of biology teachers who have taught the students, and the teachers' gender. 


\section{Methods}

\section{Respondents}

The sample consisted of 261 lower secondary school students (ISCED 2) in Slovakia, aged 14 and 15 years. A total of 125 male students (47.89\%) and 136 female students $(52.11 \%)$ participated in the research. There were 153 students from towns $(58.62 \%)$ and 108 from villages (41.38\%). The maximum number of teachers who taught the students biology was three $(n=82 ; 31.80 \%)$. Of the participating students, 27 were taught by male teachers (10.34\%) and 234 by female teachers $(89.66 \%)$.

\section{Research instrument}

A questionnaire created by the authors of the present research was used as a research instrument. It contained Likert-type items and was divided into two parts. The first part included demographic variables such as gender, residence, number of teachers who taught the students biology, and gender of the biology teachers. The second part of the questionnaire included 27 items: 8 items focused on the students' perception of the biology teacher (a dimension in the factor analysis), while the other 19 items focused on the students' perception of biology. The items had a positive $(n=16)$ or negative orientation $(n=11)$. The positive items were coded from 1 (strongly disagree) to 5 (strongly agree), while the negative items were coded in the reverse order.

\section{Data analysis}

The reliability and validity of the questionnaire was determined after data coding. The reliability was determined with Cronbach's alpha coefficient ( $\alpha)$. The boundary value for a reliable research instrument is $\alpha=.70$ (Cronbach, 1951), and the questionnaire used in the research achieved a value of $\alpha=.83$. The construct validity was determined using factor analysis. The relevance of the factor analysis was determined through the KMO index and the Bartlett test of sphericity. The value of the KMO test was .8o and the value of the Bartlett test was $\chi^{2}=2399.12, p$ $<$.oo1. Both values indicated the relevance of the factor analysis. The factor analysis divided the items into four dimensions and no item used in the instrument was deleted. The results of the factor analysis are presented in Table 1 . The value of Cronbach's alpha for the dimensions was higher than $\alpha=.50$ in all four cases, which is suitable for dimensions (Ferketich, 1991; Kline, 1993). The items were 
not always well connected with the title of the particular dimension. The titles of the dimensions are only indicative. Adequately naming dimensions is a common problem in research, as it is very likely that not every item will correctly match the title of the dimension. Problems with naming dimensions extracted using factor analysis have been discussed by Thompson (2004) and Osborne and Costello (2009). Thompson (2004) suggested that it is feasible to name dimensions only approximately, according to the items in the dimension, whereas Osborne and Costello (2009) claimed that the title of a dimension is unnecessary, as factor analysis is a statistical technique to determine construct validity. The instrument was used for the first time in the present research, and the items will be revised in future studies. This procedure was also suggested by Bryant and Yarnold (1999).

Table 1. Results of factor analysis.

\begin{tabular}{|c|c|c|c|}
\hline \multicolumn{2}{|c|}{ I. Difficulty of biology } & \multicolumn{2}{|c|}{$\alpha=0.82$} \\
\hline 1.* & I like biology. & 0.64 & \\
\hline 2. & Biology is one of the easiest school subjects for me. & 0.63 & \\
\hline 10. & We realise some experiments in biology classes. & 0.56 & \\
\hline 13. & I have a feeling of disgust when I hear the word "biology". & 0.70 & \\
\hline 14. & I feel nervous during biology experiments. & 0.53 & \\
\hline 16. & I hate biology. & 0.64 & \\
\hline 19. & I would like to have biology class as often as possible. & 0.49 & \\
\hline 20. & I am bored by biology classes. & 0.46 & \\
\hline 22. & Biology classes are demanding for me. & 0.79 & \\
\hline 23. & I have to try very hard to understand biology. & 0.74 & \\
\hline 26. & I am not interested in biology. & 0.55 & \\
\hline \multicolumn{2}{|c|}{ II. Interest in biology } & \multicolumn{2}{|c|}{$\alpha=0.51$} \\
\hline 9. & Biology classes are a lot of fun for me. & \multicolumn{2}{|c|}{0.66} \\
\hline 12. & I am tense during biology classes. & \multicolumn{2}{|c|}{0.45} \\
\hline 18. & I always learn interesting information during biology classes. & \multicolumn{2}{|c|}{0.50} \\
\hline 21. & I would like to be a biology teacher in the future. & \multicolumn{2}{|c|}{0.43} \\
\hline \multicolumn{2}{|c|}{ III. Aids and expriments in biology classes } & & $\alpha=0.60$ \\
\hline 6. & The aids used in biology classes are interesting. & & 0.58 \\
\hline 7. & Biology experiments are helpful in developing my skills. & & 0.54 \\
\hline 17. & Biology is a useless school subject. & & 0.52 \\
\hline 24. & The work with live materials in biology classes is interesting. & & 0.68 \\
\hline
\end{tabular}




\begin{tabular}{|c|c|c|c|c|c|}
\hline \multicolumn{4}{|c|}{ IV. Biology teacher perception } & & \multirow{2}{*}{$\begin{array}{r}\alpha=0.74 \\
0.78\end{array}$} \\
\hline 3. & I am interested in biology only due to our biology teacher. & & & & \\
\hline 4. & My biology teacher is teaching me a lot. & & & & 0.71 \\
\hline 5. & I hate my biology teacher. & & & & 0.62 \\
\hline 8. & $\begin{array}{l}\text { My biology teacher has a very interesting way of interpreting } \\
\text { things. }\end{array}$ & & & & 0.77 \\
\hline 11. & My biology teacher gives us very interesting project tasks. & & & & 0.62 \\
\hline 15. & My biology teacher organises very interesting excursions. & & & & 6.66 \\
\hline 25. & My biology teacher does not teach me anything. & & & & 0.71 \\
\hline 27. & $\begin{array}{l}\text { My biology teacher often organises excursions in the natural } \\
\text { environment. }\end{array}$ & & & & 0.68 \\
\hline \multicolumn{2}{|c|}{ Eigenvalue } & 6.13 & 3.12 & 2.11 & 0.65 \\
\hline \multicolumn{2}{|c|}{$\%$ of variance } & 22.71 & 11.55 & 7.83 & 7.12 \\
\hline
\end{tabular}

$\alpha$ - Cronbach's alpha

* The numbering of the items is the same as in the questionnaire.

An analysis of covariance (ANCOVA) was used to determine the influence of the teacher on the students' perception of biology as a school subject. The demographic variables (student gender, student place of residence, number of teachers who have taught the students, and gender of the teachers) were used as independent variables. The mean scores for all items and for the dimensions were dependent variables. The covariable was the mean score for the dimension regarding biology teacher perception (the fourth dimension extracted in the factor analysis; see Table 1). Before conducting ANCOVA, it was necessary to determine whether a significant relationship exists between the covariate and the dependent variable. The relationship was significant $(r=.35 ; p<.001)$, so it was possible to use ANCOVA.

\section{Results}

Table 2 presents the results of ANCOVA and the mean scores for the students' gender differences. The influence of student gender on the perception of biology was insignificant $(F=2.71 ; p=.10)$, while the influence of the covariable (i.e., biology teacher perception) was significant $(F=37.87 ; p<.001)$. After removing the influence of the covariable on the results, no statistically significant difference was detected between male and female students. 
Table 2. Values of ANCOVA and mean score with respect to gender.

\begin{tabular}{lcccc}
\hline & $\begin{array}{c}\boldsymbol{F} \text { (biology teacher } \\
\text { perception) }\end{array}$ & $\boldsymbol{F}$ (gender) & $\boldsymbol{x}$ (male) & $\boldsymbol{x}$ (female) \\
\hline overall score & $37.87^{* * *}$ & 2.71 & 3.25 & 3.32 \\
difficulty of biology & $25.37^{* * *}$ & 3.01 & 3.24 & 3.35 \\
interest in biology & $63.92^{* * *}$ & .08 & 3.13 & 3.09 \\
aids and experiments & $7.35^{* *}$ & 1.30 & 3.41 & 3.49 \\
\hline
\end{tabular}

${ }^{* *} p<.01$

${ }^{* * *} p<.001$

Similarly, for the independent variable student's residence, the differences between groups were insignificant $(F=1.09 ; p=.30)$, while the influence of the covariable (i.e., biology teacher perception) was significant $(F=35.92 ; p<.001)$ (Table 3).

Table 3. Values of ANCOVA and mean score with respect to residence.

\begin{tabular}{lcccc}
\hline & $\begin{array}{c}\boldsymbol{F} \text { (biology teacher } \\
\text { perception) }\end{array}$ & $\boldsymbol{F}$ (residence) & $\boldsymbol{x}$ (village) & $\boldsymbol{x}$ (town) \\
\hline overall score & $35.92^{* * *}$ & 1.09 & 3.34 & 3.26 \\
difficulty of biology & $23.65^{* * *}$ & 1.07 & 3.35 & 3.25 \\
interest in biology & $64.05^{* * *}$ & 0.72 & 3.15 & 3.08 \\
aids and experiments & $6.78^{* *}$ & 0.17 & 3.48 & 3.43 \\
${ }^{* *} p<.01$ & & & & \\
${ }^{* * *} p<.001$ & & & &
\end{tabular}

The number of teachers who have taught the students biology was the next variable investigated (Figure 1). In this case, the difference was statistically significant $(F=4.17 ; p<.05)$ and the covariable had a significant influence $(F=$ $35.03 ; p<.001)$. A significant difference was detected in the dimension "difficulty of biology" $(F=3.38 ; p<.05)$. 


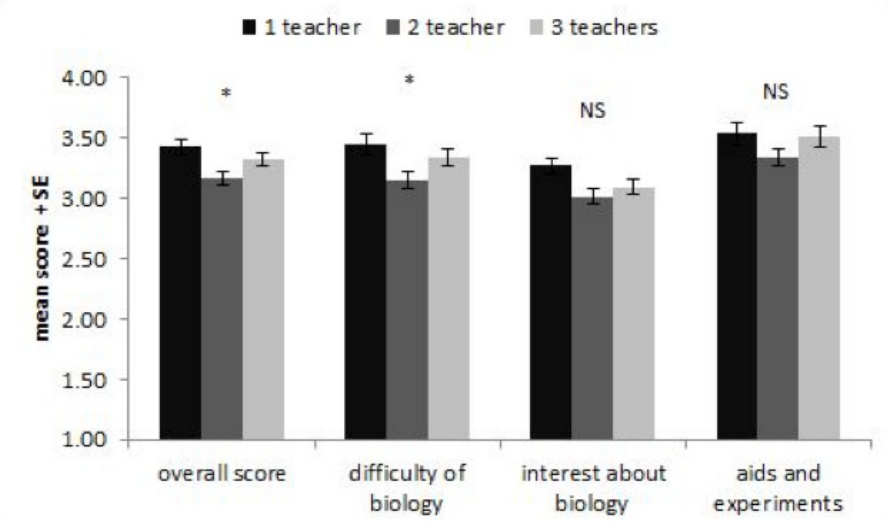

${ }^{*} p<.05$

NS - not significant difference

Figure 1. Mean score and SE regarding the number of teachers who have taught the students biology.

The influence of the teachers' gender was statistically significant $(F=5.09$; $p<.05)$, and the covariable was significant $(F=29.68 ; p<.05)$. A significant difference was detected in the dimension "interest in biology" $(F=7.97 ; p<.01)$ and in the dimension "aids and experiments" $(F=6.17 ; \mathrm{p}<.05)$ (Figure 2$).$

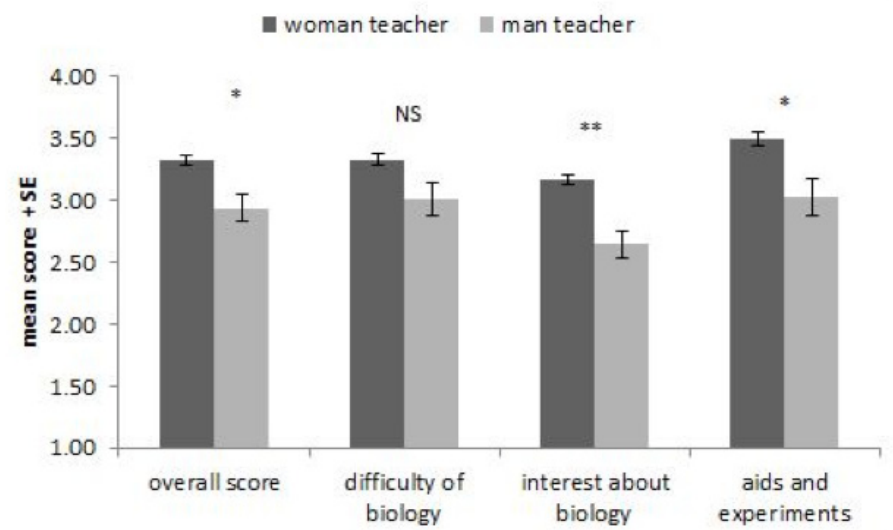

${ }^{*} p<.05$

${ }^{* *} p<.01$

$N S$ - not significant difference

Figure 2. Mean score with respect to the teachers' gender. 


\section{Discussion}

The main aim of the present research was to determine whether the teacher is an influential factor regarding lower secondary school students' perception of biology as a school subject. The results showed that female students had a more positive perception of biology than male students, but without significant effect. The influence of student gender was insignificant, but the influence of the covariable (i.e., students' perception of the biology teacher) was significant. Similar findings were reported in certain prior studies (Weinburgh \& Englehard, 1994; Uitto, 2014). Uitto (2014) found that female students were more interested in biology topics such as the human body and human behaviour, while male students prioritised school subjects that included the manipulation of objects, such as physics. The author found a statistically significant difference between male and female students in their attitudes to biology, in favour of the latter. Komarraju (2013) found that students preferred teachers who were more creative and used more than one teaching approach. This can be related to a higher preference for a school subject. The findings of the present research indicate that the biology teacher has a positive influence on male and female students' perception of biology.

The second observed independent variable was the respondents' place of residence. The difference was not significant. Similarly, Zeidan and Jayosi (2015) did not find a significant difference between respondents from villages and towns regarding their perception of science subjects. On the other hand, Sekar and Mani (2013) found that students from towns perceived science subjects more positively than students living in villages. In the present research, a significant influence of the biology teacher on results was found. This could be explained by the differing roles a teacher can play in villages and towns. A teacher in a more rural environment probably works with fewer students at a time, has more time and opportunities to work individually with students, and may also know the student privately. This could, to a certain extent, explain the positive perception of a school subject. Similar findings were discussed in studies by Berenguer, Corraliza and Martin (2005) and Glenn and Hill (1977).

Students taught only by one biology teacher had the most positive perception of biology, while students taught by two teachers had the most negative attitudes. A review of the research literature revealed no research focused on this variable. The assumption is that the participating students perceived a school subject more positively when taught by only one teacher because they were accustomed to his or her teaching style. The reverse effect could be explained when two teachers taught students: students had difficulties adapting to the new (changed) teaching style of the second teacher. There are still some questions that 
need to be answered in future studies. For example, why did the students who had been taught by three different teachers have a more positive perception than the students who had been taught by two teachers? One possibility is the indirect influence of the second teacher. If the second teacher had a negative effect on students' attitudes, the third teacher could have the reverse effect.

The last studied variable was teachers' gender. The students' perception of biology was significantly more positive when taught by a female teacher than a male teacher. There are, however, some limitations to this conclusion, as only a very small number of the participating students had a male teacher. Opdenakker and Van Damme (2006) reported that male teachers are more focused on the school subject, whereas female teachers are more focused on students, on their needs and behaviour. Similar findings were reported by Good, Sikes and Brophy (1973). Jones and Wheatley (1990) found that male teachers were stricter than female teachers, which could also have an effect on the perception of the school subject.

\section{Conclusion}

In the present study, students' perception of the teacher had an important influence on their attitudes towards biology as a school subject. After removing the influence of the teacher, students' gender and place of residence did not have any significant influence on their perception of the subject. Significant differences were detected in two variables: the number of teachers who had taught the students biology, and the teachers' gender. Based on the results of the research, it is possible to suggest some further areas of research. It would be important to study teachers' influences on other school subjects. For a thorough understanding of how class dynamics work with respect to the teacher, it would be important to use other research methods, as well; class observations of a biology teacher, for example, could confirm possible gender differences during the teaching process. As mentioned in the section regarding the research methods used, there are some relevant issues related to the distribution of items into dimensions (not all items matched the names given to the dimensions). This could be revised in future research, as suggested by Bryant and Yarnold (1999).

Based on the present findings, it is possible to suggest some practical implications for education.

1. More emphasis should be given to the selection processes of student teachers when entering universities and colleges (e.g., more information regarding their personality traits, interests and motivation) and to preservice and in-service professional development of teachers (i.e., teachers need to achieve pedagogical mastery, and to acquire good subject content 
knowledge and pedagogical-content knowledge). This will help to make school subjects more interesting and meaningful to students.

2. The circulation of subject teachers (e.g., biology teachers) during primary and secondary school education should be minimised in order to reduce the negative impacts of changing teachers on students' perception of the school subject.

3. In order to create a positive school climate, a variety of teaching and learning approaches should be practised (e.g., different teaching strategies and methods supporting creative and heuristic activity of students, cooperative learning, etc.). Biology teaching should take place outdoors as well as indoors in order to achieve maximum meaning for the students.

\section{References}

Berenguer, J., Corraliza, J. A., \& Martin, R. (2005). Rural-Urban differences in environmental concern, attitudes, and actions. European Journal of Psychological Assessment, 21(2), 128-138. Bryant, F. B., \& Yarnold, P. R. (1995). Principal-components analysis and exploratory and confirmatory factor analysis. In L. G. Grimm (Ed.), Reading and understanding multivariate statistics. (pp. 99-136) Washington, DC, US: American Psychological Association.

Byrne, C. J. (1983). Teacher knowledge and teacher effectiveness: A literature review, theoretical analysis and discussion of research strategy. Paper presented at the meeting of the Northwestern Educational Research Association, Ellenville, NY.

Cohen, E. H. (2005). Student evaluations of course and teacher: factor analysis and SSA approaches. Assessment \& Evaluation in Higher Education, 3o(2), 123-136.

Colley, A., \& Comber, C. (2003). School subject preferences: age and gender differences revisited. Educational Studies, 29(1), 59-67.

Cronbach, L. J. (1951). Coefficient alpha and the internal structure of tests. Psychometrika, 16(3), 297-334.

Darling-Hammond, L. (1999). Teacher Quality and Student Achievement: A Review of State Policy Evidence. Seattle, WA: Center for the Study of Teaching and Policy, University of Washington. Feng, L., \& Ha, J.-L. (2016). Effects of teachers' information literacy on lifelong learning and school effectiveness. Eurasia Journal of Mathematics, Science \& Technology Education, 12(6), 1653-1663 Ferketich, S. (1991). Focus on psychometrics. Aspects of item analysis. Research in Nursing \& Health, $14(2), 165-168$.

Francis, B., Hutchings, M., Archer, L., \& Melling, L. (2003). Subject choice and occupational aspirations among pupils at girls school. Pedagogy, Culture, \& Society, 11(3), 425-442.

George, R., \& Kaplan, D. (1998). A structural model of parent and teacher influences on science attitudes of eighth graders: Evidence from NELS: 88. Science Education, 92(1), 93-109.

Glenn, N. D., \& Hill, L. H. (1977). Rural-urban differences in attitudes and behavior in the United 
States. Annals of the American Academy of Political and Social Science, 429(1), 36-50.

Good, T. L., Sikes, J. N., \& Brophy, J. E. (1973). Effects of teacher sex and student sex on classroom interaction. Journal of Educational Psychology, 65(1), 74-87.

Haladyna, T., Olsen, R., \& Shaughnessy, J. (1983). Correlates of class attitude toward science. Journal of Research in Science Teaching, 20(4), 311-324.

Jones, M. G., \& Wheatley, J. (1990). Gender differences in teacher-student interactions in science classrooms. Journal of Research in Science Teaching, 27(9), 861-874.

Juttner, M., Boone, M., Park, S., \& Neuhaus, B. J. (2013). Development and use of a test instrument to measure biology teachers' content knowledge (CK) and pedagogical content knowledge (PCK).

Educational Assessment, Evaluation and Accountability, 25(1), 45-67.

Kline, M. (1993). The handbook of psychological testing. Routledge: London.

Komarraju, M. (2013). Ideal teacher behaviors: Student motivation and self-efficacy predict preferences. Teaching of Psychology, 40(2), 104-110

Luyten, J. W., \& Snijders, T. (1996). Teacher effects and school effects. Educational Research and Evaluation, 2(1), 1-24.

Myers, R. E., \& Fouts, J. T. (1992). A cluster analysis of classroom environments and attitude toward science. Journal of Research in Science Teaching, 29(9), 929-937.

Opdenakker, M., \& Van Damme, J. (2006). Teacher characteristics and teaching styles as effectiveness enhancing factors of classroom practice. Teaching and Teacher Education, 22(1), 1-22. Osborne, J. W., \& Costello, A. B. (2009). Best practices in exploratory factor analysis: Four recommendations for getting the most from your analysis. Practical Assessment, Research \& Evaluation, 10(7), 1-9.

Sekar, P., \& Mani, S. (2013). Science attitude of higher secondary students. Indian Journal of Research, $2(1), 50-52$.

Singh, K., Granville, M., \& Dika, S. (2002). Mathematics and science achievement: Effects of motivation, interest, and academic engagement. Journal of Educational Studies, 95(6), 323-332. Teppo, M., \& Rannikmäe, M. (2003). Increasing the relevance of science education 61 - student preferences for different types of teaching scenarios. Journal of Baltic Science Education, 2(4), 49-61. Thompson, B. (2004). Exploratory and confirmatory factor analysis: Understanding concepts and applications. Washington, DC: American Psychological Association.

Trumper, R. (2006). Factors affecting junior high school students' interest in biology. Science Education International, $17(1), 31-48$.

Uitto, A. (2014). Interest, attitudes and self-efficacy beliefs explaining upper-secondary school students' orientation towards biology-related careers. International Journal of Science and Mathematics Education, 12(6), 1425-1444.

Wayne, A. J., \& Young, P. (2003).Teacher characteristics and student achievement gains: A review. Review of Educational Research, 73(1), 89-122.

Weinburgh, M. H., \& Englehard, G. (1994). Gender, prior academic performance and beliefs as predictors of attitudes toward biology laboratory experiences. School Science and Mathematics, 94(3), 
$118-123$.

Zeidan, A. H. (2010). The relationship between grade 11 Palestinian attitudes toward biology and their perceptions of the biology learning environment. International Journal of Science and Mathematics Education, 8(5), 783-800.

Zeidan, A. H., \& Jayosi, M. R. (2015). Science process skills and attitudes toward science among Palestinian secondary school students. World Journal of Education, 5(1), 13-24.

\section{Biographical note}

Milan Kubiatko, $\mathrm{PhD}$, is an assistant professor at the Department of Pedagogical Studies, Faculty of Humanities, University of Zilina, Zilina, Slovakia. His work focuses on pupils and students attitudes towards the different thematic areas of science, on the problematic of alterative conceptions and students and teachers usage of information and communication technologies.

Gregor Torkar, PhD, is Associate Professor of Biology Education at the Faculty of Education University of Ljubljana, Slovenia. His work focuses on didactics of biology, environmental education and nature protection. Currently his main research interests are biodiversity education and education for sustainable development.

Lenka Rovnanova, $\mathrm{PhD}$, is an assistant professor at the Department of Pedagogy, Faculty of Education, Matej Bel University, Banska Bystrica, Slovakia. Her work focuses on the problematic of motivation toward learning and also on the teaching styles of teachers and learning styles of pupils. 